\title{
Desulfovulcanus ferrireducens gen. nov., sp. nov., a thermophilic autotrophic iron and sulfate-reducing bacterium from subseafloor basalt that grows on akaganéite and lepidocrocite minerals
}

\author{
Srishti Kashyap ${ }^{1,3} \cdot$ Masroque Musa $^{1} \cdot$ Kaylee A. Neat ${ }^{2} \cdot$ Deborah A. Leopo $^{1} \cdot$ James F. Holden $^{1}$
}

Received: 12 January 2022 / Accepted: 10 February 2022 / Published online: 21 February 2022

(c) The Author(s) 2022

\begin{abstract}
A deep-sea thermophilic bacterium, strain $\mathrm{Ax} 17^{\mathrm{T}}$, was isolated from $25^{\circ} \mathrm{C}$ hydrothermal fluid at Axial Seamount. It was obligately anaerobic and autotrophic, oxidized molecular hydrogen and formate, and reduced synthetic nanophase Fe(III) (oxyhydr)oxide minerals, sulfate, sulfite, thiosulfate, and elemental sulfur for growth. It produced up to $20 \mathrm{mM} \mathrm{Fe}^{2+}$ when grown on ferrihydrite but $<5 \mathrm{mM} \mathrm{Fe}^{2+}$ when grown on akaganéite, lepidocrocite, hematite, and goethite. It was a straight to curved rod that grew at temperatures ranging from 35 to $70{ }^{\circ} \mathrm{C}$ (optimum $65^{\circ} \mathrm{C}$ ) and a minimum doubling time of $7.1 \mathrm{~h}$, in the presence of 1.5-6\% $\mathrm{NaCl}$ (optimum 3\%) and pH 5-9 (optimum 8.0). Phylogenetic analysis based on 16S rRNA gene sequences indicated that the strain was 90-92\% identical to other genera of the family Desulfonauticaceae in the phylum Pseudomonadota. The genome of $\mathrm{Ax} 17^{\mathrm{T}}$ was sequenced, which yielded 2,585,834 bp and contained 2407 protein-coding sequences. Based on overall genome relatedness index analyses and its unique phenotypic characteristics, strain $\mathrm{Ax} 17^{\mathrm{T}}$ is suggested to represent a novel genus and species, for which the name Desulfovulcanus ferrireducens is proposed. The type strain is $\operatorname{Ax} 17^{\mathrm{T}}\left(=\operatorname{DSM} 111878^{\mathrm{T}}=\operatorname{ATCC}\right.$ TSD $\left.-233^{\mathrm{T}}\right)$.
\end{abstract}

Keywords Deep sea thermophiles · Anaerobic bacteria $\cdot$ Autotroph $\cdot$ Iron reducer $\cdot$ Sulfate reducer $\cdot$ Hydrothermal vent

\section{Introduction}

Most thermophilic chemoautotrophs studied from deep-sea hydrothermal vents are methanogens and other microbes that oxidize molecular hydrogen $\left(\mathrm{H}_{2}\right)$ and reduce sulfur compounds and nitrate (Sievert and Vetriani 2012). Less is

Communicated by A. Oren.

Draft genome and 16S rRNA gene sequences deposited in DDBJ/ENA/GenBank database under accession numbers JAGUQP000000000 and MZ048018, respectively.

James F. Holden

jholden@microbio.umass.edu

1 Department of Microbiology, University of Massachusetts, N418 Morrill IV North; 639 N. Pleasant St., Amherst, MA 01003, USA

2 Department of Astronomy, Mount Holyoke College, South Hadley, MA 01075, USA

3 Present Address: Department of Geological Sciences, University of Colorado, Boulder, CO 80309, USA known about thermophilic iron reducers that use molecular hydrogen as an electron donor and Fe(III) (oxyhydr)oxide minerals as terminal electron acceptors. These include the facultatively autotrophic bacteria Deferribacter abyssi and Deferribacter autotrophicus with optimal growth at $60{ }^{\circ} \mathrm{C}$ (Miroshnichenko et al. 2003; Slobodkina et al. 2009a), the facultatively autotrophic archaea Geoglobus ahangari and Geoglobus acetivorans with optimal growth at $81-88^{\circ} \mathrm{C}$ (Kashefi et al. 2002; Slobodkina et al. 2009b), and the chemolithoheterotrophic archaeon Pyrodictium delaneyi $\mathrm{Su} 06^{\mathrm{T}}$ with optimal growth at $90-92{ }^{\circ} \mathrm{C}$ (Lin et al. 2014, 2016; Kashyap and Holden 2021).

Ferrihydrite $\left(\mathrm{Fe}_{2} \mathrm{O}_{3} \bullet 0.5 \mathrm{H}_{2} \mathrm{O}\right)$ is the most common Fe(III) (oxyhydr)oxide mineral used for the growth of iron-reducing bacteria and archaea. It is the least crystalline iron oxide in a gradient that includes (from least to most crystalline) lepidocrocite $(\gamma-\mathrm{FeOOH})$, akaganéite $(\beta-\mathrm{FeOOH})$, maghemite $\left(\gamma-\mathrm{Fe}_{2} \mathrm{O}_{3}\right)$, goethite $(\alpha-\mathrm{FeOOH})$, and hematite $\left(\alpha-\mathrm{Fe}_{2} \mathrm{O}_{3}\right)$, which makes ferrihydrite a more favorable electron acceptor (Cornell and Schwertmann 2003). Furthermore, nanophase iron oxide minerals ( $<100 \mathrm{~nm}$ in at least one dimension) are also more reactive than their macroparticulate counterparts 
due to an increase in reactive surface area (Braunschweig et al. 2013). When tested on various synthetic nanophase $\mathrm{Fe}(\mathrm{III})$ (oxyhydr)oxides, $P$. delaneyi grew best and produced the most acid soluble $\mathrm{Fe}^{2+}$ on ferrihydrite and showed modest growth and $\mathrm{Fe}^{2+}$ production on lepidocrocite and akaganéite with poor growth and $\mathrm{Fe}^{2+}$ production on goethite and hematite (Kashyap et al. 2018). It reduced ferrihydrite to magnetite $\left(\mathrm{Fe}_{3} \mathrm{O}_{4}\right)$ (Lin et al. 2014; Kashyap et al. 2018), lepidocrocite to a ferrous carbonate mineral, and akaganéite to a ferrous phosphate mineral and magnetite (S. Kashyap and J. Holden, unpubl. results).

This study sought to isolate and characterize a thermophilic, obligate autotroph that uses synthetic nanophase akaganéite and lepidocrocite as terminal electron acceptors from low-temperature hydrothermal fluid flowing from a basalt outcrop at Axial Seamount. The goal was to determine if there are chemoautotrophic bacteria that are better adapted for growth on either nanophase akaganéite or lepidocrocite rather than nanophase ferrihydrite. A novel genus and species, Desulfovulcanus ferrireducens $\mathrm{Ax} 17^{\mathrm{T}}$, in the family Desulfonauticaceae (Waite et al. 2020) that grew as well or better on akaganéite and lepidocrocite relative to ferrihydrite was isolated and characterized and its whole genome was sequenced to determine its novelty and metabolic potential.

\section{Materials and methods}

\section{Isolation of new thermophile strains}

Hydrothermal vent samples were collected in July 2017 from Axial Seamount in the northeastern Pacific Ocean (45.9 $\mathrm{N}, 130.0^{\circ} \mathrm{W}$ ) on board the $\mathrm{R} / \mathrm{V}$ Roger Revelle using the remotely operated submarine ROV Jason II at a depth of $1513 \mathrm{~m}$. Low-temperature $\left(25^{\circ} \mathrm{C}\right)$ hydrothermal vent fluid was collected from Marker 33 vent using the NOAA Hydrothermal Fluid and Particle Sampler (Butterfield et al. 2004). The hydrothermal fluid was used to inoculate growth media (see below) that separately contained akaganéite and lepidocrocite as terminal electron acceptors and $80 \%(\mathrm{v} / \mathrm{v}) \mathrm{H}_{2}$ and $20 \%(\mathrm{v} / \mathrm{v}) \mathrm{CO}_{2}$ at $2 \mathrm{~atm}$ in the headspace as the carbon source and electron donor. The enrichments were incubated at sea at $55^{\circ} \mathrm{C}$ in a forced-air incubator for up to 7 days.

Enrichments were screened for cell growth using epifluorescence microscopy, $\mathrm{Fe}^{2+}$ production using a spectrophotometer (see below), and $\mathrm{CH}_{4}$ production in the headspace using a gas chromatograph. Enrichments that showed cell growth and evidence of iron reduction without production of $\mathrm{CH}_{4}$ were transferred at least three additional times to confirm growth. Two enrichments from Marker 33 hydrothermal vent fluid that grew at $55{ }^{\circ} \mathrm{C}$ using akaganéite and lepidocrocite as electron acceptors were separately isolated on their respective iron oxides using at least three sequential dilution-to-extinction incubations where the most dilute sample in the series to show growth was used to inoculate the next dilution series or, for the final dilution series, was used as the purified strain. 16S rRNA gene sequence analysis of the two isolates showed that they had identical sequences. Therefore, only the akaganéite-grown strain was used for further characterization and was named $\mathrm{Ax} 17^{\mathrm{T}}$.

\section{Growth conditions}

The growth medium for all laboratory experiments, except where amended (see below) was based on DSM Medium 981 (Kashefi et al. 2002) that contained (per liter) $19.0 \mathrm{~g}$ of $\mathrm{NaCl}, 9.0 \mathrm{~g}$ of $\mathrm{MgCl}_{2} \cdot 6 \mathrm{H}_{2} \mathrm{O}, 0.30 \mathrm{~g}$ of $\mathrm{CaCl}_{2} \cdot 2 \mathrm{H}_{2} \mathrm{O}$, $0.50 \mathrm{~g}$ of KCl, $0.42 \mathrm{~g}$ of $\mathrm{KH}_{2} \mathrm{PO}_{4}, 0.05 \mathrm{~g}$ of $\mathrm{NaBr}, 0.02 \mathrm{~g}$ of $\mathrm{SrCl}_{2} \cdot 6 \mathrm{H}_{2} \mathrm{O}, 0.15 \mathrm{~g}$ of $\mathrm{MgSO}_{4} \bullet 7 \mathrm{H}_{2} \mathrm{O}, 0.1 \mathrm{~g}$ of $\left(\mathrm{NH}_{4}\right)_{2} \mathrm{SO}_{4}$, $1.0 \mathrm{~g}$ of $\mathrm{NaHCO}_{3}, 0.16 \mathrm{~g}$ of $\mathrm{FeCl}_{2}$ (for iron grown cultures), $10 \mathrm{ml}$ of DSM Medium 141 trace element solution, and $10 \mathrm{ml}$ of DSM Medium 141 vitamin solution. In the absence of iron as a terminal electron acceptor (see below), $50 \mu \mathrm{l}$ of a $0.5 \%(w / v)$ resazurin solution was added as a redox indicator. The medium was $\mathrm{pH}$ balanced to $6.80 \pm 0.05$ (room temperature) and $0.5 \mathrm{mM}$ cysteine- $\mathrm{HCl}$ was added prior to inoculation as the reducing agent. Cultures were grown in sealed Balch tubes and serum bottles sealed with butyl rubber stoppers and $80 \%(\mathrm{v} / \mathrm{v}) \mathrm{H}_{2}$ and $20 \%(\mathrm{v} / \mathrm{v}) \mathrm{CO}_{2}$ at $2 \mathrm{~atm}$ in the headspace in a forced-air incubator. Strain $\mathrm{Ax} 17^{\mathrm{T}}$ was incubated at $55{ }^{\circ} \mathrm{C}$ unless otherwise stated.

Nanophase akaganéite, lepidocrocite, ferrihydrite, goethite, and hematite (each $100 \mathrm{mmol} F$ (III) (oxyhydr)oxide per liter) were separately tested as terminal electron acceptors. They were synthesized and kept at $4{ }^{\circ} \mathrm{C}$ in the dark in concentrated aqueous solutions as previously described (Sklute et al. 2018). Other terminal electron acceptors tested were $20 \mathrm{mM} \mathrm{Fe}$ (III)-citrate, $7.0 \mathrm{mM}$ sodium sulfate, $7.9 \mathrm{mM}$ sodium sulfite, $6.3 \mathrm{mM}$ sodium thiosulfate, $1 \%(\mathrm{w} / \mathrm{v})$ elemental sulfur (equivalent to $313 \mathrm{mmol}$ total sulfur per liter or $40 \mathrm{mmol}$ cyclooctasulfur per liter), $9.9 \mathrm{mM}$ potassium nitrate, $40 \%(\mathrm{v} / \mathrm{v}) \mathrm{H}_{2}$ and $10 \%(\mathrm{v} / \mathrm{v}) \mathrm{CO}_{2}$ in air at $2 \mathrm{~atm}$, and $100 \%$ air at 2 atm. $80 \%(\mathrm{v} / \mathrm{v}) \mathrm{H}_{2}$ and $20 \%$ (v/v) $\mathrm{CO}_{2}$ at 2 atm, $10 \mathrm{mM}$ each of D-glucose, D-maltose, L-alanine, ethanol, glycerol, and sodium salts of formate, acetate, pyruvate, citrate, and succinate; $0.5 \%(\mathrm{w} / \mathrm{v})$ tryptone (pancreatic digest of casein, Oxoid Ltd.); and $0.02 \%$ (w/v) Bacto yeast extract (Becton, Dickinson and Company) were tested separately as carbon and electron donors using $80 \%(\mathrm{v} / \mathrm{v}) \mathrm{N}_{2}$ and $20 \%$ (v/v) $\mathrm{CO}_{2}$ at $2 \mathrm{~atm}$ in the headspace (except for the $\mathrm{H}_{2}: \mathrm{CO}_{2}$ condition).

For kinetic experiments, strain $\mathrm{Ax} 17^{\mathrm{T}}$ was grown in triplicate on ferrihydrite at temperatures ranging from 30 to $75{ }^{\circ} \mathrm{C}$; at $\mathrm{pH} 4$ (no buffer), pH 5 and $6(5 \mathrm{mM}$ MES buffer) $\mathrm{pH} 7$ and 8 (20 mM PIPES buffer), and pH 8 and $9(100 \mathrm{mM}$ EPPS buffer); and $0.11 \mathrm{M}$ to $1.26 \mathrm{M}$ chloride to determine 
their effect on growth. A pH above $\mathrm{pH} 9$ was not sustainable with incubation, and therefore not tested. Strain $\mathrm{Ax} 17^{\mathrm{T}}$ was also grown in duplicate on akaganéite, lepidocrocite, ferrihydrite, goethite, hematite, sodium sulfate, elemental sulfur, and control medium without an added electron acceptor. Each of these was matched with an uninoculated control. At various time points, an aliquot from each bottle was preserved with $2 \%$ formaldehyde (v/v) and mixed $1: 1$ in a filter-sterilized anoxic oxalate solution (0.23 M ammonium oxalate-0.17 M oxalic acid, Phillips and Lovley 1987) to dissolve the iron oxide minerals (when present). The concentration of cells in each bottle was determined by epifluorescence microscopy (Hobbie et al. 1977). Cells were filtered onto a $0.2-\mu \mathrm{m}$-pore-size membrane filter pre-stained with Irgalan black (Whatman), stained with $0.1 \%$ (w/v) acridine orange for $2 \mathrm{~min}$, and counted with a Nikon Eclipse E400 microscope. The specific growth rate of the culture was determined by a best-fit curve to the logarithmic portion of the growth data. Total oxalate fixed ferrous iron and $\mathrm{Zn}$ fixed sulfide concentrations were determined spectrophotometrically using the ferrozine assay (Phillips and Lovley 1987) and the methylene blue assay (Chen and Mortenson 1977), respectively. Confidence intervals (95\%) were calculated for all specific growth rates and an ANCOVA and Tukey tests ( $\alpha=0.05$ ) were run on specific growth rates for the varying terminal electron acceptors as described previously (Zar 1996).

\section{Electron microscopy}

For negative staining of whole mounted cells, $10 \mathrm{ml}$ of culture within a sealed Balch tube were fixed by adding $0.2 \mathrm{ml}$ of $50 \%(\mathrm{v} / \mathrm{v})$ electron microscopy-grade glutaraldehyde with gentle mixing and incubating at room temperature for $1 \mathrm{~h}$. An aliquot $(3 \mathrm{ml})$ of the fixed culture was then removed from the sealed Balch tube and applied to plasma-treated carbon films (ca. $0.5 \mathrm{~nm}$ thickness) on 400 mesh copper grids. The grids were stained with $3 \%(\mathrm{w} / \mathrm{v}) \mathrm{NH}_{4} \mathrm{OH}$ and $2 \%$ $(\mathrm{w} / \mathrm{v})$ aqueous uranyl acetate and viewed with a JEOL-100S transmission electron microscope.

\section{5 rRNA gene and genome sequence analyses}

The genomic DNA of strain $\mathrm{Ax} 17^{\mathrm{T}}$ was extracted and purified using a Wizard genomic DNA purification kit (Promega, USA) per the manufacturer's protocol. The 16S rRNA gene was amplified using the polymerase chain reaction (PCR) and sequenced. The bacterial primers used were $27 \mathrm{f}-\mathrm{CM}$ (5'-AGAGTTTGATCMTGGCTCAG-3', Frank et al. 2008) and 1492r (5'-GGTTACCTTGTTACGACTT-3', Wilson et al. 1990) as one PCR pair and 338f (5'-ACTCCTACG GGAGGCAGC-3', Whitely and Bailey 2000) and 1391r (5'-GACGGGCRGTGWGTRCA-3', Brunk and Eis 1998) as another pair (Integrated DNA Technologies). Each PCR reaction contained $21.5 \mu \mathrm{l}$ of nuclease-free water (Fisher BioReagents), $3 \mu$ l of $10 \times$ Omni Klentaq mutant reaction buffer (DNA Polymerase Technology), $2.4 \mu \mathrm{l}$ of $2.5 \mu \mathrm{M}$ dNTPs (Promega), $1 \mu \mathrm{l}$ each of $10 \mu \mathrm{M}$ forward and reverse primers, $0.1 \mu \mathrm{l}$ of Omni Klentaq DNA polymerase (DNA Polymerase Technology, Inc.), and $1 \mu \mathrm{l}$ of DNA template. The PCR consisted of $96^{\circ} \mathrm{C}$ for 5 min followed by 30 cycles of $95^{\circ}$ for $30 \mathrm{~s}, 54^{\circ} \mathrm{C}$ for $30 \mathrm{~s}$, and $68^{\circ} \mathrm{C}$ for $30 \mathrm{~s}$, then $68^{\circ} \mathrm{C}$ for $5 \mathrm{~min}$ followed by $25^{\circ} \mathrm{C}$ for $1 \mathrm{~min}$. The PCR products were cleaned using a DNA Clean \& Concentrator Kit (Zymo Research) and sequenced using Sanger sequencing in the forward and reverse directions (Genewiz, Inc.). A consensus sequence was derived from the combined sequences. Phylogenetic trees were constructed using 16S rRNA gene sequences from NCBI using the Maximum Likelihood method and Tamura-Nei model (Tamura and Nei 1993). Evolutionary analyses were conducted in MEGA X (Kumar et al. 2018). The $16 \mathrm{~S}$ rRNA gene sequence for $A x 17^{\mathrm{T}}$ was deposited at DDBJ/ENA/GenBank under the accession number MZ048018.

Following genomic DNA extraction as described above, library construction for whole genome sequencing was performed using a NexteraXT DNA library prep kit (Illumina, USA) per the manufacturer's protocol. Both library construction and sequencing were performed by Genewiz, Inc. (South Plainfield, NJ, USA). The DNA was sequenced using a MiSeq instrument (Illumina, USA) with $2 \times 150$ bp chemistry. Default parameters were used for all software analyses. Trimmomatic version 0.36 (Bolger et al. 2014) was used to trim the last $8 \mathrm{bp}$ of each sequence and regions with low-quality $\mathrm{Q}$ scores $(\mathrm{Q}<30)$. The resulting pairedend sequences were then assembled using SPAdes genome assembler version 3.10 (Nurk et al. 2013). The completeness of the genome sequence was determined using CheckM (Park et al. 2015). Open reading frames (ORFs) were identified using EMBOSS tools (Rice et al. 2000) and annotated using Diamond BLASTp (Buchfink et al. 2015). Hydrogenases were classified using HydDB (Søndergaard et al. 2016) and Type IV pili proteins were identified using PilFind version 1.0 (Imam et al. 2011). rRNA genes were identified using RNAmmer version 1.2 (Lagesen et al. 2007) and tRNA genes were identified using tRNAscan-SE version 2.0 (Lowe and Chan 2016). This whole genome shotgun sequencing project was deposited at DDBJ/ENA/GenBank under the accession number JAGUQP000000000. The version described in this paper is version JAGUQP010000000. The raw reads were deposited in the Sequence Read Archive under run number SUB8811277 and BioProject number PRJNA688464.

For overall genome relatedness index (OGRI) analyses, the BLAST-based average nucleotide identity (ANI) and Alignment Fraction (AF) scores were calculated using the 
JSpeciesWS program, version 3.2.2 (Richter et al. 2016). Genome-to-genome direct comparison (GGDC) analyses were performed using Eq. 2 in the GGDC program, version 2.1 (Meier-Koltoff et al. 2013). Default parameters were used for all software analyses. Forty marker proteins defined for the Species Identification (SpecI) analyses (Mende et al. 2013) were compared using BLAST-P. Ribosomal multilocus sequence typing (rMLST) analyses (Jolley et al. 2012) were performed by trimming and concatenating 50 ribosomal protein sequences from 10 whole genome sequences in NCBI and aligning them using the Maximum Likelihood method and a Jones-Taylor-Thorton matrix-based model (Jones et al. 1992). Evolutionary analyses were conducted in MEGA X (Kumar et al. 2018).

\section{Results and discussion}

\section{Phenotypic characteristics}

Strain $\mathrm{Ax} 17^{\mathrm{T}}$ is an obligately anaerobic, thermophilic autotroph. Electron microscopy revealed straight to curved rods, $1.5 \mu \mathrm{m}$ by $0.4 \mu \mathrm{m}$, with monopolar flagellation (Fig. 1). It grew on akaganéite, lepidocrocite, ferrihydrite, hematite, goethite, sulfate, sulfite, thiosulfate, and elemental sulfur as terminal electron acceptors (Table 1). At its optimal growth temperature, the specific growth rate of strain $\mathrm{Ax} 17^{\mathrm{T}}$ was highest when grown on akaganéite $\left(0.079 \mathrm{~h}^{-1} \pm 0.013 \mathrm{~h}^{-1}, 95 \%\right.$ confidence interval $)$ followed by growth on lepidocrocite $\left(0.073 \mathrm{~h}^{-1} \pm 0.017 \mathrm{~h}^{-1}\right)$ and ferrihydrite $\left(0.072 \mathrm{~h}^{-1} \pm 0.013 \mathrm{~h}^{-1}\right)$, which were not significantly different (Fig. 2). Specific growth rates were lower when hematite $\left(0.045 \mathrm{~h}^{-1} \pm 0.010 \mathrm{~h}^{-1}\right)$, goethite $\left(0.033 \mathrm{~h}^{-1} \pm 0.004 \mathrm{~h}^{-1}\right)$, sulfate $\left(0.053 \mathrm{~h}^{-1} \pm 0.005 \mathrm{~h}^{-1}\right)$, and elemental sulfur $\left(0.029 \mathrm{~h}^{-1} \pm 0.003 \mathrm{~h}^{-1}\right)$ were used as terminal electron acceptors (Fig. 2). Strain $\mathrm{Ax} 17^{\mathrm{T}}$ produced up to $20 \mathrm{mM} \mathrm{Fe}^{2+}$ when grown on ferrihydrite relative to abiotic controls but $<5 \mathrm{mM} \mathrm{Fe}^{2+}$ when grown on akaganéite, lepidocrocite, hematite, and goethite. Strain $\mathrm{Ax} 17^{\mathrm{T}}$ did not grow when $\mathrm{Fe}(\mathrm{III})$-citrate, nitrate, or oxygen was supplied as the electron acceptor nor in the absence of an added electron acceptor.

Strain $\mathrm{Ax} 17^{\mathrm{T}}$ only used molecular hydrogen and formate separately as electron donors and did not utilize acetate, glucose, tryptone, pyruvate, citrate, succinate, ethanol, glycerol, or yeast extract as an alternative source of carbon and electrons (Table 1). Growth was observed on molecular hydrogen and ferrihydrite between 35 and $70{ }^{\circ} \mathrm{C}$ with an optimum of $65^{\circ} \mathrm{C}$ (Fig. 3a), between pH 5.0 and 9.0 with an optimum of pH 8.0 (Fig. 3b), and between $0.21 \mathrm{M}$ and $0.84 \mathrm{M} \mathrm{Cl}^{-}$with an optimum of $0.42 \mathrm{M} \mathrm{Cl}^{-}$(Fig. 3c). Its minimum doubling time was $7.1 \mathrm{~h}$.

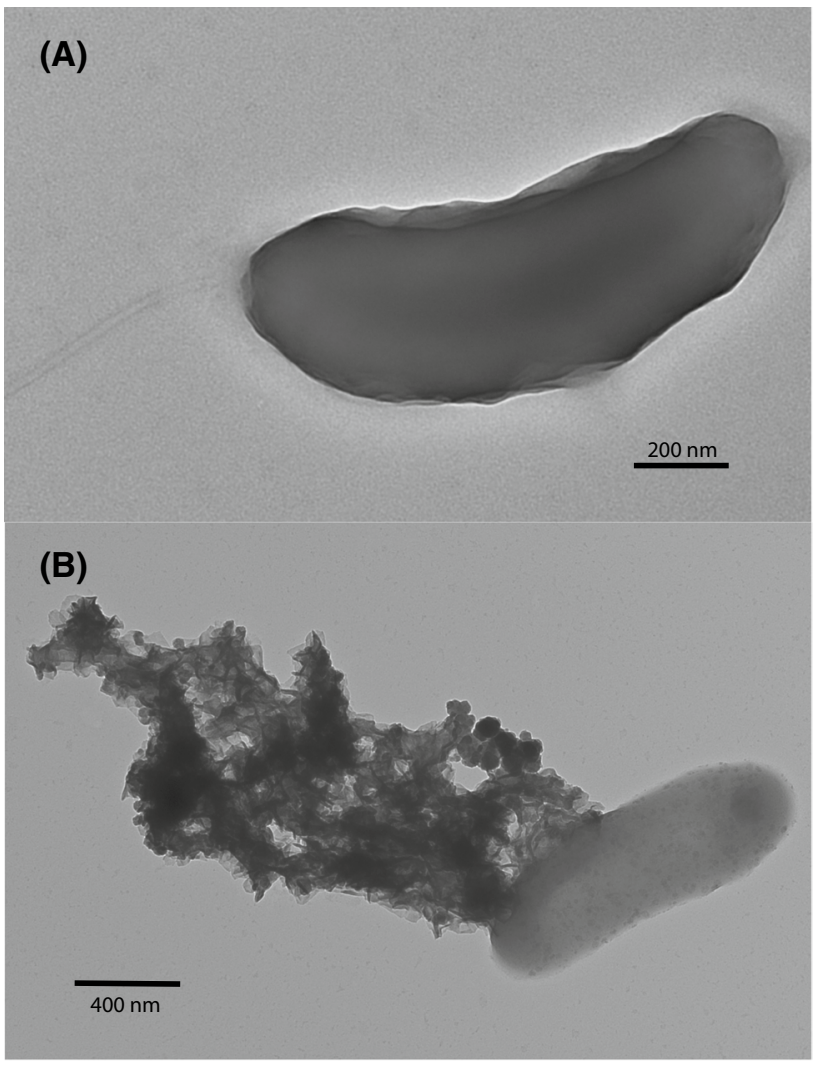

Fig. 1 Transmission electron micrograph of strain Ax17 $17^{\mathrm{T}}$ showing a a rod-shaped cell with a monopolar flagellum and $\mathbf{b}$ a rod-shaped cell with transformed akaganéite following growth on the mineral

\section{S rRNA phylogenetic analysis}

The 16S rRNA sequence obtained from the whole genome sequence was nearly identical (1427 of 1429 nucleotides) to the consensus sequence obtained by PCR and was used as the final 16S rRNA sequence for the organism. Based on its $16 \mathrm{~S}$ rRNA gene sequence, strain $\mathrm{Ax} 17^{\mathrm{T}}$ was most closely related to members of the family Desulfonauticaceae (Waite et al. 2020) (Fig. 4) in the phylum Pseudomonadota (Oren and Garrity 2021). It showed highest sequence identities to Desulfonauticus autotrophicus $\mathrm{TeSt}^{\mathrm{T}}$ (90.68\%), Desulfonauticus submarinus $6 \mathrm{~N}^{\mathrm{T}}$ (90.61\%), Desulfonatronovibrio hydrogenovorans Z-7935 ${ }^{\mathrm{T}}$ (90.95\%), and Desulfonatronospira thiodismutans ASO3$1^{\mathrm{T}}(86.69 \%)$ (Table 1). Each of these sequence identities were below the $98.7 \%$ identity demarcation for a novel species (Chun et al. 2018), the $94.5 \%$ identity demarcation for a novel genus (Yarza et al. 2014), and the $92.25 \%$ identity for family but above the order demarcation $(89.20 \%$ identity) using the 'Yarza medians' (Boden et al. 2017). 
Table 1 Differential characteristics of $\mathrm{Ax} 17^{\mathrm{T}}$ and members of the families Desulfonauticaceae and Desulfonotronovibrionaceae

\begin{tabular}{|c|c|c|c|c|c|}
\hline Characteristics $^{\mathrm{a}}$ & $\mathrm{Ax} 17^{\mathrm{T}}$ & $\begin{array}{l}\text { Desulfonauticus sub- } \\
\text { marinus } 6 \mathrm{~N}^{\mathrm{T}}\end{array}$ & $\begin{array}{l}\text { Desulfonauticus auto- } \\
\text { trophicus } \mathrm{TeSt}^{\mathrm{T}}\end{array}$ & $\begin{array}{l}\text { Desulfonatronovi- } \\
\text { brio hydrogenovo- } \\
\text { rans } \\
\text { Z- } 7935^{\mathrm{T}}\end{array}$ & $\begin{array}{l}\text { Desulfonatrono- } \\
\text { spira thiodismutans } \\
\text { ASO3- } 1^{\mathrm{T}}\end{array}$ \\
\hline Habitat & $\begin{array}{l}\text { Hydrothermal vent, } \\
\text { Axial Seamount, } \\
\text { Pacific Ocean }\end{array}$ & $\begin{array}{l}\text { Hydrothermal vent, } \\
13^{\circ} \text { N East Pacific } \\
\text { Rise, Pacific Ocean }\end{array}$ & $\begin{array}{l}\text { Oil reservoir, Ham- } \\
\text { burg, Germany }\end{array}$ & $\begin{array}{l}\text { Lake Magadi, } \\
\text { Kenya }\end{array}$ & $\begin{array}{l}\text { Kulanda Steppe, } \\
\text { Russia }\end{array}$ \\
\hline $\begin{array}{l}\text { 16S rRNA gene iden- } \\
\text { tity }(\%)\end{array}$ & 100 & 90.61 & 90.68 & 90.95 & 86.69 \\
\hline \multicolumn{6}{|l|}{ OGRI analyses } \\
\hline ANI $(\%)$ & 100 & 67.22 & ND & 66.66 & 65.93 \\
\hline $\mathrm{AF}$ & 100 & 0.2943 & ND & 0.2922 & 0.2480 \\
\hline GGDC (\%) & 100 & 21.0 & ND & 19.6 & 23.2 \\
\hline SpecI $(\%)$ & 100 & 77.4 & ND & 76.2 & 74.2 \\
\hline rMLST (\%) & 100 & 77.7 & ND & 75.6 & ND \\
\hline \multicolumn{6}{|l|}{ Morphology } \\
\hline Cell shape & Straight to curved rods & Curved rods & Straight to curved rods & Vibrio & Vibrio to spirillum \\
\hline Length $(\mu \mathrm{m})$ & 1.5 & $5-6$ & $1.2-4$ & $1.5-2$ & $2-30$ \\
\hline Width $(\mu \mathrm{m})$ & 0.4 & $0.4-0.5$ & 0.6 & 0.5 & $0.6-0.8$ \\
\hline Flagellation & Monopolar & Monopolar & Monopolar & Monopolar & Monopolar \\
\hline $\begin{array}{l}\text { Temperature range of } \\
\text { growth and (opti- } \\
\text { mum) }\left({ }^{\circ} \mathrm{C}\right)\end{array}$ & $35-70(65)$ & $30-60(45)$ & $40-64(58)$ & $22-40(37)$ & up to 43 \\
\hline $\begin{array}{l}\mathrm{pH} \text { range of growth } \\
\text { and (optimum) }\end{array}$ & $5.0-9.0(8.0)$ & $(7.0)$ & (7.0) & 8-10.2 (9.5-9.7) & $8.3-10.5(10)$ \\
\hline $\begin{array}{l}\mathrm{NaCl} \text { range of growth } \\
\text { and (optimum) (\%) }\end{array}$ & $1.5-6(3)$ & $0-5(2)$ & $1-6(3)$ & $1-12(3)$ & $8.7-23.2$ \\
\hline $\begin{array}{l}\text { Minimum doubling } \\
\text { time }\end{array}$ & $7.1 \mathrm{~h}$ & ND & $80 \mathrm{~min}$ & ND & ND \\
\hline \multicolumn{6}{|l|}{ Electron donors } \\
\hline $\mathrm{H}_{2}$ & + & $+{ }^{\mathrm{b}}$ & $+{ }^{\mathrm{b}}$ & $+{ }^{\mathrm{bc}}$ & + \\
\hline Formate & + & $+{ }^{\mathrm{b}}$ & $+{ }^{\mathrm{b}}$ & $+{ }^{b c}$ & + \\
\hline Acetate & - & - & - & - & + \\
\hline Pyruvate & - & ND & - & - & + \\
\hline Glucose & - & - & - & - & ND \\
\hline \multicolumn{6}{|l|}{ Electron acceptors } \\
\hline Fe(III) oxides ${ }^{\mathrm{d}}$ & + & ND & ND & ND & ND \\
\hline $\mathrm{Fe}(\mathrm{III})$ citrate & - & ND & - & ND & ND \\
\hline Sulfate & + & + & + & + & + \\
\hline Sulfite & + & + & + & + & + \\
\hline Thiosulfate & + & + & + & + & + \\
\hline Elemental sulfur & + & + & + & - & - \\
\hline Nitrate & - & - & - & - & ND \\
\hline Oxygen & - & - & - & - & - \\
\hline
\end{tabular}

+ Positive; - negative; $N D$ not determined

${ }^{a}$ Data from Zhilina et al. 1997; Audiffin et al. 2003; Sorokin et al. 2008; Mayilraj et al. 2009

${ }^{\mathrm{b}}$ Growth on $\mathrm{H}_{2}+$ acetate or formate + acetate

${ }^{\mathrm{c}}$ Yeast extract requirement for growth

${ }^{\mathrm{d}}$ Ferrihydrite, lepidocrocite, akagenéite, goethite, and hematite, each tested separately 


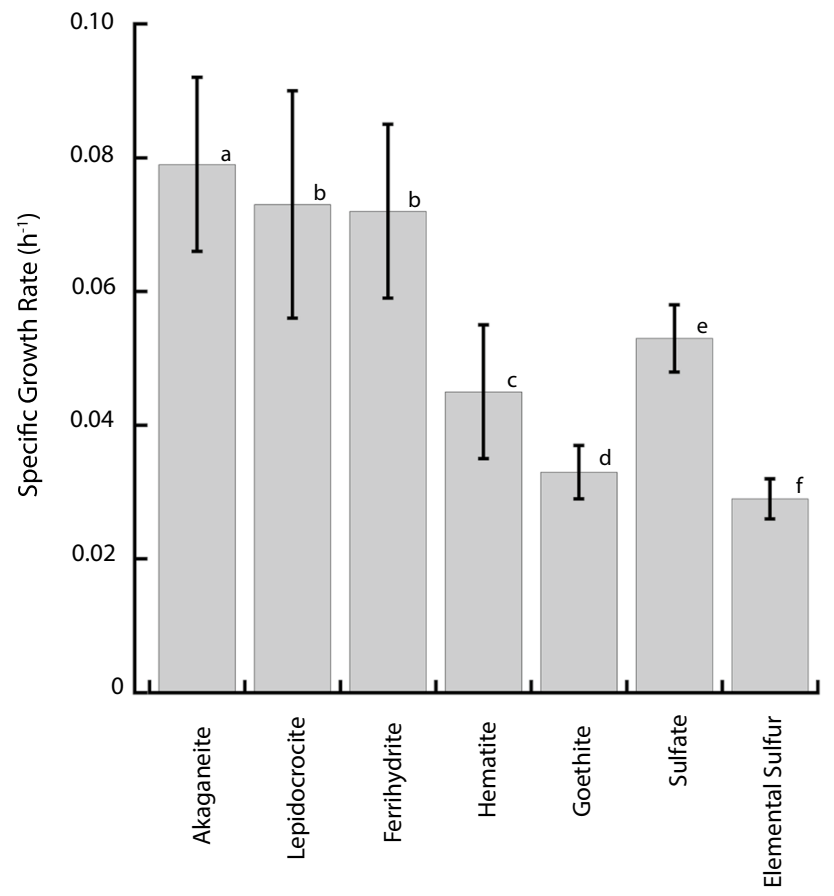

Fig. 2 Specific growth rates for strain $\mathrm{Ax} 17^{\mathrm{T}}$ when grown on varying terminal electron acceptors. The error bars represent $95 \%$ confidence intervals. The letters represent statistically different groups of rates $(p<0.05)$ following an analysis of covariance and a Tukey test

\section{Genome sequence analysis}

Whole genome sequencing using a MiSeq instrument generated a total of 18,566,594 raw paired-end reads and $5,570 \mathrm{Mb}$ of sequenced bases. Genome assembly resulted in 60 high-quality contigs, with an $N_{50}$ value of 77,684 bp and a maximum contig length of $262,489 \mathrm{bp}$. The assembled Ax $17^{\mathrm{T}}$ genome was $2,585,834$ bp long and $98.2 \%$ complete with $>2,000$-fold average coverage resulting in 2,407 protein-coding genes and a $\mathrm{G}+\mathrm{C}$ content of $42.5 \%$. One copy each of the 5S, $16 \mathrm{~S}$, and 23S rRNA genes, and 60 tRNA genes were identified.

OGRI analyses also showed that strain $\mathrm{Ax} 17^{\mathrm{T}}$ was generally most closely related to $D$. submarinus $6 \mathrm{~N}^{\mathrm{T}}$ (Table 1 ). The ANI and AF scores for strain comparisons between Ax $17^{\mathrm{T}}$ and D. submarinus $6 \mathrm{~N}^{\mathrm{T}}$ were $67.2 \%$ and 0.2943 , between $\mathrm{Ax} 17^{\mathrm{T}}$ and $D$. hydrogenovorans $\mathrm{Z}-7935^{\mathrm{T}}$ were

Fig. 3 Specific growth rates for strain $\mathrm{Ax} 17^{\mathrm{T}}$ across its growth range of a temperature, $\mathbf{b} \mathrm{pH}$, and $\mathbf{c}$ chlorinity. The error bars represent $95 \%$ confidence intervals
$66.7 \%$ and 0.2922 , and between $\mathrm{Ax} 17^{\mathrm{T}}$ and $D$. thiodismutans ASO3- $1^{\mathrm{T}}$ were $65.9 \%$ and 0.2480 , which were all below the ANI $96 \%$ cut-off and $0.6 \mathrm{AF}$ values for species determination (Chun et al. 2018) and the ANI 73.1-74.0\% cut-off value for genus determination (Barco et al. 2020) by this approach. The GGDC scores for strain comparisons between $\mathrm{Ax} 17^{\mathrm{T}}$ and D. thiodismutans ASO3- $1^{\mathrm{T}}$ was $23.2 \%$, between $\mathrm{Ax} 17^{\mathrm{T}}$ and D. submarinus $6 \mathrm{~N}^{\mathrm{T}}$ was $21.0 \%$, and between $\mathrm{Ax} 17^{\mathrm{T}}$ and D. hydrogenovorans $\mathrm{Z}-7935^{\mathrm{T}}$ was $19.6 \%$ (Table 1), which were all below the $70 \%$ cut-off for delineating species by this approach (Chun et al. 2018). The SpecI-type protein analysis for strain $\mathrm{Ax} 17^{\mathrm{T}}$ gave values of $77.4 \%$ for $D$. submarinus $6 \mathrm{~N}^{\mathrm{T}}, 76.2 \%$ for $D$. hydrogenovorans $\mathrm{Z}-7935^{\mathrm{T}}$, and $74.2 \%$ for D. thiodismutans ASO3- ${ }^{\mathrm{T}}$ (Table 1), which are all below the $96.5 \%$ cut-off for delineating species by this approach (Mende et al. 2013). Therefore, all three OGRI analyses indicated that strain $\mathrm{Ax} 17^{\mathrm{T}}$ represents a novel genus and species. The rMLST phylogenetic tree confirmed that $\mathrm{Ax} 17^{\mathrm{T}}$ was most closely related to D. submarinus $6 \mathrm{~N}^{\mathrm{T}}$ (Fig. 5).

Like strain $\mathrm{Ax} 17^{\mathrm{T}}$, D. submarinus, D. autotrophicus, and $D$. hydrogenovorans only use molecular hydrogen and formate as electron donors, although the latter organisms must simultaneously use acetate as a carbon source and $D$. hydrogenovorans requires yeast extract for growth (Table 1) (Zhilina et al. 1997; Audiffin et al. 2003; Mayilraj et al. 2009). Only strain $\mathrm{Ax} 17^{\mathrm{T}}$ grew only on $\mathrm{H}_{2}$ and $\mathrm{CO}_{2}$ alone. Strain $\mathrm{Ax} 17^{\mathrm{T}}$ is also phenotypically similar to D. submarinus and D. autotrophicus based on its thermophilic optimal growth temperature and its ability to use sulfate, sulfite, thiosulfate, and elemental sulfur as electron acceptors (Table 1).

The $\mathrm{Ax} 17^{\mathrm{T}}$ draft genome contains putative genes that based on sequence identity at the amino acid level encode for a periplasmic [NiFe] cytochrome $c$ hydrogenase (Group 1b, EC 1.12.2.1), a periplasmic [FeFe] cytochrome $c$ hydrogenase (Group A1, EC 1.12.2.1), a cytoplasmic NAD(P)-reducing hydrogenase (Group A, EC 1.12.1.5), a cytoplasmic $\mathrm{H}_{2}$ : $\mathrm{CoB}-\mathrm{CoM}$ heterodisulfide and ferredoxin reductase (Group 3c, EC 1.8.98.5), and a cytoplasmic $[\mathrm{FeFe}]$ ferredoxin-reducing hydrogenase (Group B, EC 1.12.7.2) using the classification system of Greening et al. (2016). It has putative genes for two periplasmic formate:cytochrome $c$ dehydrogenases (EC 1.17.2.3) that provide the organism with electrons and contributes to a proton motive force, a membrane-bound menaquinone
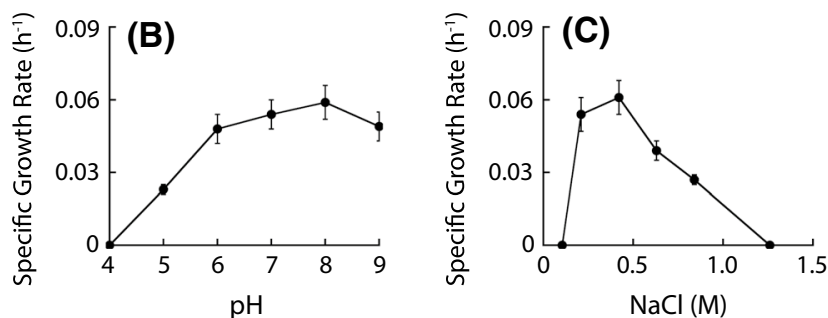
Fig. 4 Phylogenetic tree based on the 16S rRNA gene showing the position of $\mathrm{Ax} 17^{\mathrm{T}}$ within the order Desulfovibrionales including at a minimum the type strain of every genus. After 1000 bootstrap constructions, the tree with the highest log likelihood $(-10,800)$ is shown, with values next to nodes indicating the percentage of reconstructions in which the topology was preserved (values $<70 \%$ are omitted for clarity). There were a total of $1472 \mathrm{nt}$ positions in the final dataset. Branch lengths are to scale and indicate the number of substitutions per site; bar, 5 substitutions per site. The outgroup is Desulfurobacterium thermolithotrophum $\mathrm{BSA}^{\mathrm{T}}$ from the phylum Aquificota (formerly Aquificae). GenBank/EMBL/ DDBJ accession numbers are included in parentheses
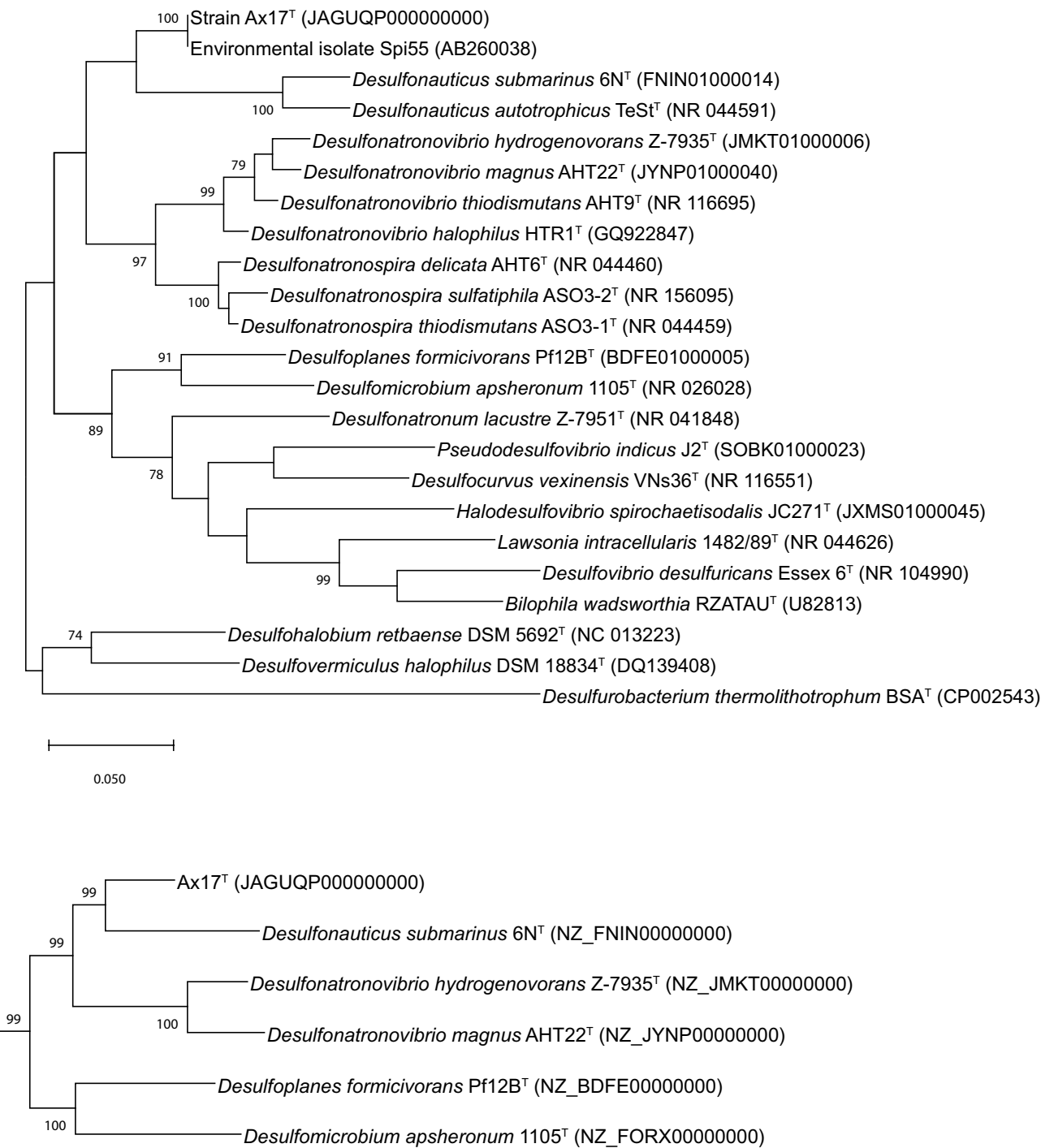

Desulfurobacterium thermolithotrophum BSA $^{\top}$ (NC_015185)

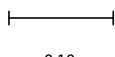

0.10

Fig. 5 Phylogenetic tree of strain $\mathrm{Ax} 17^{\mathrm{T}}$ as inferred using ribosomal multilocus sequence typing (rMLST) of 50 concatenated ribosomal protein amino acid sequences. The tree with the highest log likelihood $(-87,485)$ is shown. The percentage of trees in which the associated taxa clustered together is shown next to the branches $(>70 \%)$.
The tree is drawn to scale, with branch lengths measured in the number of substitutions per site. There was a total of 7,340 positions in the final dataset. The outgroup is Desulfurobacterium thermolithotrophum $\mathrm{BSA}^{\mathrm{T}}$ from the phylum Aquificota (formerly Aquificae). Gen$\mathrm{Bank} / \mathrm{EMBL} / \mathrm{DDBJ}$ accession numbers are included in parentheses reductase (QrcABCD, EC 7.1.1.8) that further contributes to a proton motive force, and a membrane-bound F-type ATP synthase (EC 7.1.2.2) that likely use the proton motive force for oxidative phosphorylation (Fig. 6).
The draft genome also contains putative genes that based on sequence identity at the amino acid level encodes for 9 monoheme $c$-type cytochromes and $10 c$-type cytochromes with two or more hemes, based on the presence of $\mathrm{CXXCH}$ 


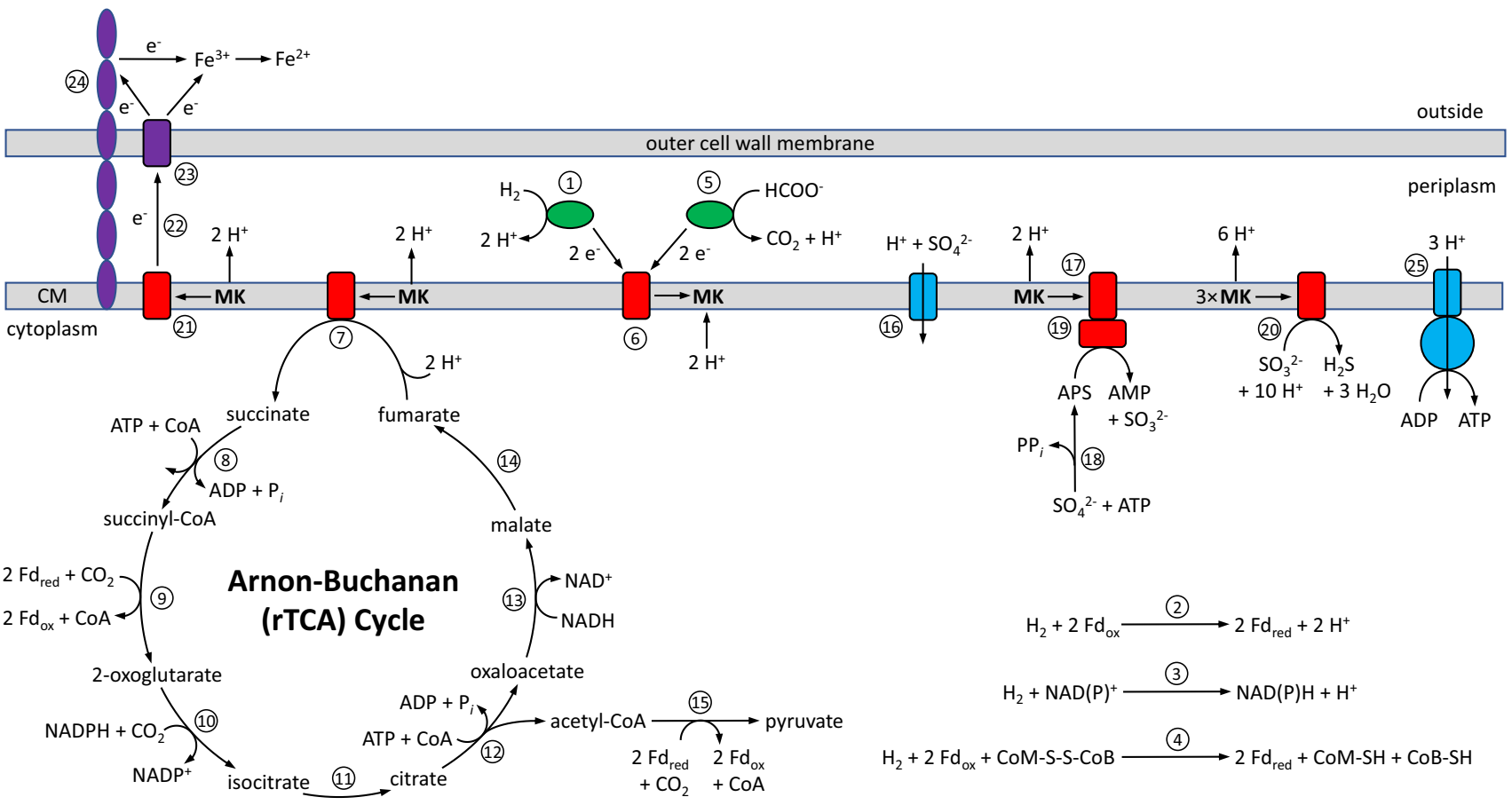

Fig. 6 Proposed electron transport, energy generation, and $\mathrm{CO}_{2}$ fixation in strain $\mathrm{Ax} 17^{\mathrm{T}}$ based on bioinformatic analyses of its whole genome sequence. The putative enzymes are as follows: 1, periplasmic $[\mathrm{NiFe}]$ and $[\mathrm{FeFe}]$ cytochrome $c$ hydrogenases (EC 1.12.2.1); 2, cytoplasmic ferredoxin (Fd)-reducing hydrogenase (EC 1.12.7.2); 3, cytoplasmic $\mathrm{NAD}(\mathrm{P})^{+}$-reducing hydrogenase (EC 1.12.1.5); 4, cytoplasmic $\mathrm{H}_{2}$ : $\mathrm{CoB}-\mathrm{CoM}$ heterodisulfide and ferredoxin reductase (EC 1.8.98.5); 5, periplasmic formate:cytochrome $c$ dehydrogenase (EC 1.17.2.3); 6, membrane-bound menaquinone reductase (EC 7.1.1.8); 7, fumarate reductase (EC 1.3.5.4); 8, succinyl-CoA synthetase (EC 6.2.1.5); 9, 2-oxoglutarate:ferredoxin oxidoreductase (EC 1.2.7.3); 10 , isocitrate dehydrogenase (EC 1.1.1.42); 11, aconitate hydratase

motifs and a signal peptide sequence (Gomi et al. 2004). The genome contains 12 type IV pilin-like signal peptides and their prepilin peptidase cleavage sites. One of these contains $\geq 9.8 \%$ aromatic amino acids with aromatic gaps of 23 amino acids or less, which suggests it is an electrically conductive pili (Walker et al. 2018; Bray et al. 2020), and another that shared 58\% sequence identity with the type IV conductive pili from Geobacter sulfurreducens. The genome also contains putative genes for sulfate reduction: sulfate adenylyltransferase (Sat, EC 2.7.7.4), quinone-interacting membrane-bound oxidoreductase (QmoABC, EC 7.1.1.8), adenylylsulfate reductase (AprAB, EC 1.8.99.2), and dissimilatory sulfite reductase (DsrMKJOPABDC, EC 1.8.99.5) (Fig. 6). The genome contains putative genes that encode for all the proteins of the Arnon-Buchanan Cycle (i.e., the reductive TCA (rTCA) cycle), including ATP citrate lyase (EC 2.3.3.8), for $\mathrm{CO}_{2}$ fixation (Fig. 6).

Strain $\mathrm{Ax} 17^{\mathrm{T}}$ was isolated from low-temperature $\left(25{ }^{\circ} \mathrm{C}\right)$ hydrothermal fluid emanating from a basalt outcrop at Marker 33 on Axial Seamount. Reactive transport
(EC 4.2.1.3); 12, ATP citrate lyase (EC 2.3.3.8); 13, malate dehydrogenase (EC 1.1.1.37); 14, fumarate hydratase (EC4.2.1.2); 15, pyruvate:ferredoxin oxidoreductase (EC 1.2 .7 .1$) ; 16, \mathrm{H}^{+}: \mathrm{SO}_{4}{ }^{2-}$ symporter; 17, quinone-interacting membrane-bound oxidoreductase (EC 7.1.1.8), 18, sulfate adenylyltransferase (EC 2.7.7.4); 19, adenylylsulfate reductase (EC 1.8.99.2); 20, dissimilatory sulfite reductase (EC 1.8.99.5); 21, putative membrane $c$-type cytochrome; 22, putative periplasmic $c$-type cytochrome; 23, putative outer membrane $c$-type cytochrome; 24 , putative e-pilin; and 25, membrane-bound ATP synthase (EC 7.1.2.2). $M K$ menaquinone; $F d$ ferredoxin; $C o A$ coenzyme A; $C o M-S-S-C o B$ heterodisulfide; $C o M$ reduced coenzyme M-SH; $\mathrm{CoB}-\mathrm{SH}$ reduced coenzyme B

modeling suggests there is considerable molecular hydrogen consumption by thermophiles at this and another lowtemperature vent (Marker 113) at Axial Seamount (Stewart et al. 2019). Metagenomic analyses of vent fluids collected at these two sites showed that Desulfonauticaceae comprised $0.6-0.9 \%$ of the metagenomic reads of Marker 33 fluids and $1.7-1.9 \%$ of the reads of Marker 113 fluids (Fortunato et al. 2018). Strain $A x 17^{\mathrm{T}}$ showed $100 \%$ 16S rRNA gene sequence similarity with environmental isolate Spi55 from Ocean Drilling Program borehole 1026B (Fig. 4). Spi55 was a sulfate-reducing bacterium isolated from black rust removed from the borehole seal on Ocean Drilling Program (ODP) Hole 1026B on the ridge flank of the Juan de Fuca Ridge (Nakagawa et al. 2006). Strain $A x 17^{\mathrm{T}}$ was also closely related to environmental 16S rRNA gene clones 1026B15 and 1026B_19 from fluid pumped from within the sealed borehole at ODP Hole 1026B (Cowen et al. 2003; Jungbluth et al. 2014). These clones comprised $31 \%$ and $5 \%$ of the total clones isolated from this site. A similar clone (Dan60_14E) was found in 2 of 40 clones sequenced from 
production water from a high-temperature oil reservoir in the North Sea (Gittel et al. 2009). The results demonstrate the importance of metabolic versatility of thermophilic autotrophs, including Fe(III) (oxyhydr)oxide mineral reduction, that should be considered when studying $\mathrm{CO}_{2}$ fixation in various hot subseafloor environments. Furthermore, the isolation of strain $\mathrm{Ax} 17^{\mathrm{T}}$ using akaganéite and lepidocrocite provides an example of how alternative Fe(III) (oxyhydr) oxide minerals could aid in future efforts to identify other novel iron-reducing strains.

\section{Description of Desulfovulcanus gen. nov}

Desulfovulcanus (De.sul.fo.vul.ca' nus L. pref. de, from; L. neut. n. sulfur, sulfur; L. masc. n. vulcanus, god of fire; N.L. neut. n. Desulfovulcanus, sulfate reducer from a volcano).

Cells are curved to straight rods. Strictly anaerobic. Thermophilic. Chemolithoautotrophic. Able to utilize molecular hydrogen and formate as electron donors and Fe(III) (oxyhydr)oxide minerals, sulfate, sulfite, thiosulfate, and elemental sulfur as electron acceptors. Sodium chloride $(\mathrm{NaCl})$ is absolutely required for growth. Phylogenetically, the genus Desulfovulcanus belongs to the family Desulfonauticaceae. The type species is Desulfovulcanus ferrireducens.

\section{Description of Desulfovulcanus ferrireducens sp. nov}

Desulfovulcanus ferrireducens (fer.ri.re.du'cens L. neut. n. ferrum, iron; L. pres. part. reducens bringing back, leading back; N.L. part. adj. ferrireducens, iron-reducing).

Cells are Gram negative, curved to straight rods with monopolar flagellation, and approximately $1.5 \mu \mathrm{m}$ in length and $0.4 \mu \mathrm{m}$ in width. Growth occurs between 35 and $70{ }^{\circ} \mathrm{C}$, pH 5.0 and 9.0, and 1.5 and 6.0\% $\mathrm{NaCl}$. Strictly anaerobic. Chemolithoautotrophic growth occurs with hydrogen and formate as the electron donor and nanophase Fe(III) (oxyhydr)oxide (akaganéite, lepidocrocite, ferrihydrite, hematite, geothite), sulfate, sulfite, thiosulfate, and elemental sulfur as the electron acceptor. No growth is observed when acetate, glucose, tryptone, pyruvate, citrate, succinate, ethanol, glycerol, or yeast extract is used as the electron donor and carbon source. No growth on Fe(III)-citrate, nitrate, or oxygen or purely by fermentation. The genomic DNA G $+\mathrm{C}$ content of the type strain is $42.5 \%$ based on total genome calculations.

The type strain, Ax $17^{\mathrm{T}}\left(=\mathrm{DSM} 111878^{\mathrm{T}}=\mathrm{ATCC}\right.$ TSD-233 ${ }^{\mathrm{T}}$ ) was isolated from low-temperature hydrothermal vent fluid at Axial Seamount, Juan de Fuca Ridge, in the northeastern Pacific Ocean. The GenBank/EMBL/ DDBJ accession numbers for the $16 \mathrm{~S}$ rRNA gene and draft genome sequence of the type strain are MZ048018 and JAGUQP000000000, respectively.
Acknowledgements Special thanks to the pilots and crew of HOV Jason II and R/V Roger Revelle for sample acquisition, Dr. William W. Chadwick, Jr. of Oregon State University for access to the sample site, Dr. David A. Butterfield of the University of Washington for hydrothermal fluid samples, the electron microscopy facility at Mount Holyoke College for providing the electron micrograph, and Dr. Julie A. Huber of the Woods Hole Oceanographic Institution and Dr. Caroline S. Fortunato of Widener University for providing metagenomic data for Marker 33 and Marker 113 vents at Axial Seamount.

Funding This work was financially supported by NASA Exobiology grant 80NSSC18K1296 to JFH, NASA Earth and Space Science Fellowship grant $80 \mathrm{NSSC} 18 \mathrm{~K} 1243$ to SK and JFH, and by a Zonta International Amelia Earhart Fellowship to SK.

\section{Declarations}

Conflict of interest The authors declare that there are no conflicts of interest.

Ethical approval The article does not contain any studies related to human participants or animals.

Open Access This article is licensed under a Creative Commons Attribution 4.0 International License, which permits use, sharing, adaptation, distribution and reproduction in any medium or format, as long as you give appropriate credit to the original author(s) and the source, provide a link to the Creative Commons licence, and indicate if changes were made. The images or other third party material in this article are included in the article's Creative Commons licence, unless indicated otherwise in a credit line to the material. If material is not included in the article's Creative Commons licence and your intended use is not permitted by statutory regulation or exceeds the permitted use, you will need to obtain permission directly from the copyright holder. To view a copy of this licence, visit http://creativecommons.org/licenses/by/4.0/.

\section{References}

Audiffrin C, Cayol JL, Joulian C, Casalot L, Thomas P, Garcia JL, Ollivier B (2003) Desulfonauticus submarinus gen. nov., sp. nov., a novel sulfate-reducing bacterium isolated from a deepsea hydrothermal vent. Int J Syst Evol Microbiol 53:1585-1590. https://doi.org/10.1099/ijs.0.02551-0

Barco RA, Garrity GM, Scott JJ, Amend JP, Nealson KH, Emerson D (2020) A genus definition for Bacteria and Archaea based on standard genome relatedness index. Mbio 11:e02475-e2519. https://doi.org/10.1128/mBio.02475-19

Boden R, Hutt LP, Rae AW (2017) Reclassification of Thiobacillus aquaesulis (Wood \& Kelly, 1995) as Annwoodia aquasulis gen. nov., comb. nov., transfer of Thiobacillus (Beijerinck, 1904) from the Hydrogenophilales to the Nitrosomonadales, proposal of Hydrogenophilalia class. nov. within the 'Proteobacteria', and four new families within the orders Nitrosomonadales and Rhodocyclales. Int J Syst Evol Microbiol 67:1191-1205. https://doi. org/10.1099/ijsem.0.001927

Bolger AM, Lohse M, Usadel B (2014) Trimmomatic: a flexible trimmer for Illumina sequence data. Bioinformatics 30:2144-2120. https://doi.org/10.1093/bioinformatics/btu170

Braunschweig J, Bosch J, Meckenstock RU (2013) Iron oxide nanoparticles in geomicrobiology: from biogeochemistry to 
bioremediation. New Biotechnol 30:793-802. https://doi.org/10. 1016/j.nbt.2013.03.008

Bray MS, Wu J, Padilla CC, Stewart FJ, Fowle DA, Henny C, Simister RL, Thompson KJ, Crowe SA, Glass JB (2020) Phylogenetic and structural diversity of aromatically dense pili from environmental metagenomes. Environ Microbiol Rep 12:49-57. https://doi.org/ 10.1111/1758-2229.12809

Brunk CF, Eis N (1998) Quantitative measure of small-subunit rRNA gene sequences of the kingdom Korarchaeota. Appl Environ Microbiol 64:5064-5066. https://doi.org/10.1128/AEM.64.12. 5064-5066.1998

Buchfink B, Xie C, Huson DH (2015) Fast and sensitive protein alignment using DIAMOND. Nat Methods 12:59-60. https://doi.org/ 10.1038/nmeth.3176

Butterfield DA, Roe KK, Lilley MD, Huber JA, Baross JA, Embley RW, Massoth GJ (2004) Mixing, reaction and microbial activity in the sub-seafloor revealed by temporal and spatial variation in diffuse flow vents at Axial Volcano. In: Wilcock WSD, DeLong EF, Kelley DS, Baross JA, Cary SC (eds) The Subseafloor Biosphere at Mid-Ocean Ridges, Geophysical Monograph 144. American Geophysical Union, Washington, DC, pp 269-289

Chen JS, Mortenson LE (1977) Inhibition of methylene blue formation during determination of the acid-labile sulfide of iron-sulfur protein samples containing dithionite. Anal Biochem 79:157-165. https://doi.org/10.1016/0003-2697(77)90390-6

Chun J, Oren A, Ventosa A, Christensen H, Ruiz Arahal D, da Costa MS, Rooney AP, Yi H, Xu XW, De Meyer S, Trujillo ME (2018) Proposed minimal standards for the use of genome data for the taxonomy of prokaryotes. Int J Syst Evol Microbiol 68:461-466. https://doi.org/10.1099/ijsem.0.002516

Cornell RM, Schwertmann U (2003) The iron oxides: structure properties reactions, occurrences and uses. Wiley, Hoboken

Cowen JP, Giovannoni SJ, Kenig F, Johnson HP, Butterfield RMS, Lam P (2003) Fluids from aging ocean crust that support microbial life. Science 299:120-123. https://doi.org/10.1126/science.1075653

Fortunato CS, Larson B, Butterfield DA, Huber JA (2018) Spatially distinct, temporally stable microbial populations mediate biogeochemical cycling at and below the seafloor in hydrothermal vent fluids. Environ Microbiol 20:769-784. https://doi.org/10.1111/ 1462-2920.14011

Frank JA, Reich CI, Sharma S, Weisbaum JS, Wilson BA, Olsen GJ (2008) Critical evaluation of two primers commonly used for amplification of bacterial 16S rRNA genes. Appl Environ Microbiol 74:2461-2470. https://doi.org/10.1128/AEM.02272-07

Gittel A, Sørensen KB, Skovhus TL, Ingvorsen K, Schramm A (2009) Prokaryotic community structure and sulfate reducer activity in water from high-temperature oil reservoirs with and without nitrate treatment. Appl Environ Microbiol 75:7086-7096. https:// doi.org/10.1128/AEM.01123-09

Gomi M, Sonoyama M, Mitaku S (2004) High performance system for signal peptide prediction: SOSUIsignal. Chem Bio Info J 4:142-147. https://doi.org/10.1273/cbij.4.142

Greening C, Biswas A, Carere CR, Jackson CJ, Taylor MC, Stott MB, Cook GM, Morales SE (2016) Genomic and metagenomic surveys of hydrogenase distribution indicate $\mathrm{H}_{2}$ is a widely utilized energy source for microbial growth and survival. ISME J 10:761-777. https://doi.org/10.1038/ismej.2015.153

Hobbie JE, Daley RJ, Jasper S (1977) Use of nucleopore filters for counting bacteria by fluorescence microscopy. Appl Environ Microbiol 33:1225-1228. https://doi.org/10.1128/aem.33.5.12251228.1977

Imam S, Chen Z, Roos DS, Pohlschröder M (2011) Identification of surprisingly diverse Type IV pili, across a broad range of Grampositive bacteria. PLoS ONE 6:e28919. https://doi.org/10.1371/ journal.pone.0028919
Jolley KA, Bliss CM, Bennett JS, Bratcher HB, Brehony C, Colles FM, Wimalarathna H, Harrison OB, Sheppard SK, Cody AJ, Maiden MCJ (2012) Ribosomal multilocus sequence typing: universal characterization of bacteria from domain to strain. Microbiology 158:1005-1015. https://doi.org/10.1099/mic.0.055459-0

Jones DT, Taylor WR, Thornton JM (1992) The rapid generation of mutation data matrices from protein sequences. Comp Appl Biosci 8:275-282. https://doi.org/10.1093/bioinformatics/8.3.275

Jungbluth SP, Lin HT, Cowen JP, Glazer BT, Rappé MS (2014) Phylogenetic diversity of microorganisms in subseafloor crustal fluids from Holes 1025C and 1026B along the Juan de Fuca Ridge flank. Front Microbiol 5:119. https://doi.org/10.3389/fmicb.2014.00119

Kashefi K, Tor JM, Holmes DE, Gaw Van Praagh CV, Reysenbach AL, Lovley DR (2002) Geoglobus ahangari gen. nov., sp. nov., a novel hyperthermophilic archaeon capable of oxidizing organic acids and growing autotrophically on hydrogen with Fe(III) serving as the sole electron acceptor. Int J Syst Evol Microbiol 52:719-728. https://doi.org/10.1099/ijs.0.01953-0

Kashyap S, Holden JF (2021) Microbe-mineral interaction and novel proteins for iron oxide mineral reduction in the hyperthermophilic crenarchaeon Pyrodictium delaneyi. Appl Environ Microbiol 87:e02330-e2420. https://doi.org/10.1128/AEM.02330-20

Kashyap S, Sklute EC, Dyar MD, Holden JF (2018) Reduction and morphological transformation of synthetic nanophase iron oxide minerals by hyperthermophilic archaea. Front Microbiol 9:1550. https://doi.org/10.3389/fmicb.2018.01550

Kumar S, Stecher G, Li M, Knyaz C, Tamura K (2018) MEGA X: molecular evolutionary genetics analysis across computing platforms. Mol Biol Evol 35:1547-1549. https://doi.org/10.1093/ molbev/msy096

Lagesen K, Hallin P, Rødland EA, Staerfeldt HH, Rognes T, Ussery DW (2007) RNAmmer: consistent and rapid annotation of ribosomal RNA genes. Nucleic Acids Res 35:3100-3108. https:// doi.org/10.1093/nar/gkm160

Lin TJ, Breves EA, Dyar MD, Ver Eecke HC, Jamieson JW, Holden JF (2014) Magnetite formation from ferrihydrite by hyperthermophilic archaea from Endeavour Segment, Juan de Fuca Ridge hydrothermal vent chimneys. Geobiology 12:200-211. https:// doi.org/10.1111/gbi.12083

Lin TJ, El Sebae G, Jung JH, Jung DH, Park CS, Holden JF (2016) Pyrodictium delaneyi sp. nov., a hyperthermophilic autotrophic archaeon that reduces Fe(III) oxide and nitrate. Int J Syst Evol Microbiol 66:3372-3376. https://doi.org/10.1099/ijsem.0. 001201

Lowe TM, Chan PP (2016) tRNAscan-SE On-line: integrating search and context for analysis of transfer RNA genes. Nucleic Acids Res 44:W54-W57. https://doi.org/10.1093/nar/gkw413

Mayilraj S, Kaksonen AH, Cord-Ruwisch R, Schumann P, Spröer C, Tindall BJ, Spring S (2009) Desulfonauticus autotrophicus sp. nov., a novel thermophilic sulfate-reducing bacterium isolated from oil-production water and emended description of the genus Desulfonauticus. Extremophiles 13:247-255. https://doi.org/10. 1007/s00792-008-0212-4

Meier-Koltoff JP, Auch AF, Klenk HP, Göker M (2013) Genome sequence-based species delimitation with confidence intervals and improved distance functions. BMC Bioinform 14:60. https://doi.org/10.1186/1471-2105-14-60

Mende DR, Sunagawa S, Zeller G, Bork P (2013) Accurate and universal delineation of prokaryotic species. Nat Methods 10:881884. https://doi.org/10.1038/nmeth. 2575

Miroshnichenko ML, Slobodkin AI, Kostrikina NA, L'Haridon S, Nercessian O, Spring S, Stackebrandt E, Bonch-Osmolovskaya EA, Jeanthon C (2003) Deferribacter abyssi sp. nov., an anaerobic thermophile from deep-sea hydrothermal vents of the MidAtlantic Ridge. Int J Syst Evol Microbiol 53:1637-1641. https:// doi.org/10.1099/ijs.0.02673-0 
Nakagawa S, Inagaki F, Suzuki Y, Steinsbu BO, Lever MA, Takai K, Engelen B, Sako Y, Wheat CG, Horikoshii K, Integrated Ocean Drilling Program Expedition 301 Scientists (2006) Microbial community in black rust exposed to hot ridge flank crustal fluids. Appl Environ Microbiol 72:6789-6799. https://doi.org/10. 1128/AEM.01238-06

Nurk S, Bankevich A, Antipov D, Gurevich A, Korobeynikov A, Lapidus A, Prjibelsky A, Pyshkin A, Sirotkin A, Sirotkin Y, Stepanauskas R, McLean J, Lasken R, Clingenpeel SR, Woyke T, Tesler G, Alekseyev MA, Pevzner PA (2013) Assembling genomes and mini-metagenomes from highly chimeric reads. In: Deng M, Jiang R, Sun F, Zhang X (eds) Research in Computational Molecular Biology, RECOMB 2013, Lecture Notes in Computer Science, vol 7821. Springer, Heidelberg, pp 158-170

Oren A, Garrity GM (2021) Valid publication of the names of forty-two phyla of prokaryotes. Int J Syst Evol Microbiol 71:005056. https:// doi.org/10.1099/ijsem.0.005056

Parks DH, Imelfort M, Skennerton CT, Hugenholtz P, Tyson GW (2015) CheckM: assessing the quality of microbial genomes recovered from isolates, single cells, and metagenomes. Genome Res 25:1043-1055. https://doi.org/10.1101/gr.186072.114

Phillips EJP, Lovley DR (1987) Determination of Fe(III) and Fe(II) in oxalate extracts of sediment. Soil Sci Soc Am J 51:938-941. https://doi.org/10.2136/sssaj1987.03615995005100040021x

Rice P, Longden I, Bleasby A (2000) EMBOSS: the European molecular biology open software suite. Trends Genet 16:276-277. https:// doi.org/10.1016/s0168-9525(00)02024-2

Richter M, Rosselló R, Oliver Glöckner F, Peplies J (2016) JSpeciesWS: a web server for prokaryotic species circumscription based on pairwise genome comparison. Bioinformatics 32:929931. https://doi.org/10.1093/bioinformatics/btv681

Sievert SM, Vetriani C (2012) Chemoautotrophy at deep-sea vents: past, present, and future. Oceanography 25:218-233. https://doi. org/10.5670/oceanog.2012.21

Sklute EC, Kashyap S, Dyar MD, Holden JF, Tague T, Wang P, Jaret SJ (2018) Spectral and morphological characteristics of synthetic nanophase iron (oxyhydr)oxides. Phys Chem Miner 45:1-26. https://doi.org/10.1007/s00269-017-0897-y

Slobodkina GB, Kolganova TV, Chernyh NA, Querellou J, BonchOsmolovskaya EA, Slobodkin AI (2009a) Deferribacter autotrophicus sp. nov., an iron(III)-reducing bacterium from a deepsea hydrothermal vent. Int J Syst Evol Microbiol 59:1508-1512. https://doi.org/10.1099/ijs.0.006767-0

Slobodkina GB, Kolganova TV, Querellou J, Bonch-Osmolovskaya EA, Slobodkin AI (2009b) Geoglobus acetivorans sp. nov., an iron(III)-reducing archaeon from a deep-sea hydrothermal vent. Int J Syst Evol Microbiol 59:2880-2883. https://doi.org/10.1099/ ijs.0.011080-0

Søndergaard D, Pedersen CNS, Greening C (2016) HydDB: a web tool for hydrogenase classification and analysis. Sci Rep 6:34212. https://doi.org/10.1038/srep34212

Sorokin DY, Tourova TP, Henstra AM, Stams AJM, Galinski EA, Muyzer G (2008) Sulfidogenesis under extremely haloalkaline conditions by Desulfonatronospira thiodismutans gen. nov., sp. nov., and Desulfonatronospira delicata sp. nov.-a novel lineage of Deltaproteobacteria from hypersaline soda lakes. Microbiology 154:1444-1453. https://doi.org/10.1099/mic.0.2007/015628-0

Stewart LC, Algar CK, Fortunato CS, Larson BI, Vallino JJ, Huber JA, Butterfield DA, Holden JF (2019) Fluid geochemistry, local hydrology, and metabolic activity define methanogen community size and composition in deep-sea hydrothermal vents. ISME J 13:1711-1721. https://doi.org/10.1038/s41396-019-0382-3

Tamura K, Nei M (1993) Estimation of the number of nucleotide substitutions in the control region of mitochondrial DNA in humans and chimpanzees. Mol Biol Evol 10:512-526. https://doi.org/10. 1093/oxfordjournals.molbev.a040023

Waite DW, Chuvochina M, Pelikan C, Parks DH, Yilmaz P, Wagner M, Loy A, Naganuma T, Nakai R, Whitman WB, Hahn MW, Kuever J, Hugenholtz P (2020) Proposal to reclassify the proteobacterial classes Deltaproteobacteria and Oligoflexia, and the phylum Thermodesulfobacteria into four phyla reflecting major functional capabilities. Int J Syst Evol Microbiol 70:5972-6016. https://doi. org/10.1099/ijsem.0.004213

Walker DJF, Adhikari RY, Holmes DE, Ward JE, Woodard TL, Nevin KP, Lovely DR (2018) Electrically conductive pili from pilin genes of phylogenetically diverse microorganisms. ISME J 12:4858. https://doi.org/10.1038/ismej.2017.141

Whiteley AS, Bailey MJ (2000) Bacterial community structure and physiological state within an industrial phenol bioremediation system. Appl Environ Microbiol 66:2400-2407. https://doi.org/ 10.1128/aem.66.6.2400-2407.2000

Wilson KH, Blitchington RB, Greene RC (1990) Amplification of bacterial 16S ribosomal DNA with polymerase chain reaction. J Clin Microbiol 28:1942-1946. https://doi.org/10.1128/jcm.28.9. 1942-1946.1990

Yarza P, Yilmaz P, Pruesse E, Glöckner FO, Ludwig W, Schleifer KH, Whitman WB, Euzéby J, Amann R, Rosselló-Móra R (2014) Uniting the classification of cultured and uncultured bacteria and archaea using 16S rRNA gene sequences. Nat Rev Microbiol 12:635-645. https://doi.org/10.1038/nrmicro3330

Zar JH (1996) Biostatistical Analysis, 3rd edn. Prentice Hall, Upper Saddle River

Zhilina TN, Zavarzin GA, Rainey FA, Pikuta EN, Osipov GA, Kostrikina NA (1997) Desulfonatronovibrio hydrogenovorans gen. nov., sp. nov., an alkaliphilic, sulfate-reducing bacterium. Int J Syst Bacteriol 47:144-149. https://doi.org/10.1099/00207 713-47-1-144

Publisher's Note Springer Nature remains neutral with regard to jurisdictional claims in published maps and institutional affiliations. 